\title{
VOLATILITY MEASURES, LIQUIDITY AND CREDIT LOSS PROVISIONS DURING PERIODS OF FINANCIAL DISTRESS
}

\author{
GIULIO ANSELMI \\ Università Cattolica del Sacro Cuore \\ Largo Gemelli, 1, Milano, Italy \\ giulio.anselmi@unicatt.it \\ Received 18 October 2017 \\ Accepted 23 May 2018 \\ Published 4 July 2018
}

\begin{abstract}
In this paper, we investigate the role of liquidity in banks lending activity and how liquidity provision is related to bank's credit risk and others market-based risk measures, such as bank's implied volatility skew from options traded on the market and realized volatility from futures contract on LIBOR, during periods of global financial distress. Credit risk is given by the ratio between loan loss reserves and total assets and we find that losses from lending activity force banks to build up new liquidity provisions only during the period of financial distress. Liquidity ratio is given by the sum of cash and short-term assets over total assets and we discovered that credit risk reduces liquidity ratio only in bad times, as this demand for liquid asset is suddenly switched on and the more reserves from loan losses the bank has, the more it cleans its balance sheet from long-term commitments in order to replenish its cash and short-term securities. When we control for market-based risk measures, we evidence that both implied volatility skew and LIBOR's realized volatility are negatively related with the liquidity ratio and are useful in predicting a distress in bank's liquidity holdings.
\end{abstract}

Keywords: Liquidity risk; financial institutions; volatility measures; market discipline.

\section{Introduction}

In this paper, we analyze the effects of credit risk measures and market-based volatility risk measures on liquidity provisions and lending activity conducted by banks' and other financial institutions during periods of global financial stability and periods of global financial distress. Regarding the importance of liquidity provision tools, we offer market-based perspectives on what might influence banks' liquidity. This study is novel because it introduces market-based volatility measures as factors explaining liquidity provision activities undertaken by banks and because it introduces loan loss reserves ratio as a variable linked to liquidity provisions and granting of new loans. We find that losses from lending activity force banks to build up new

This is an Open Access article published by World Scientific Publishing Company. It is distributed under the terms of the Creative Commons Attribution 4.0 (CC-BY) License. Further distribution of this work is permitted, provided the original work is properly cited. 
liquidity provisions only during the period of financial distress. On the other hand, during the period of financial stability, new loans are crippled from losses experienced by the banks in the previous quarter. Regarding the liquidity ratio, we use cash and short-term securities over total asset as a proxy of overall liquidity provisions available for the firm. We discovered that, in good times, credit risk reduces the liquidity ratio and does not trigger the liquid asset demand for banks while, in bad times, this demand for liquid asset is suddenly switched on and the more reserves from loan losses the bank has, the more its cleans its balance sheet from long-term commitments in order to replenish its cash and short-term securities. When we control for market-based risk measures, we evidence that both implied volatility skew and LIBOR's realized volatility are negatively related with the liquidity ratio and are useful in predicting a distress in bank's liquidity holdings.

During the 2007-2009 Financial Crisis, the banking sector froze its inter-banking activity experiencing a severe drawdown in banks' liquidity and defaults. Since then, liquidity provisioning has become a critical principle to account for by everyone involved in loans market, for commercial and investment banks, central banks and other regulators. In order to set things back to normality, central banking authorities implemented broad measures to provide liquidity to commercial and non-commercial banking sectors. Meanwhile regulators drafted a liquidity coverage criterion to prevent future liquidity distress — both in inter-banking activity and in customers' deposits — and to reinforce banking sector stability, supporting capital regulations standards where they are less effective.

To address this issue, Basel Committee presented the Liquidity Coverage Ratio (LCR) in January $2013^{\text {a }}$ which has the goal to promote short-term resilience of the liquidity risk profile of banks. The principle behind LCR is that banks must hold a minimum high-quality liquid asset (HQLA) buffer portfolio that can be easily and immediately converted into cash in private markets in order to meet sudden liquidity needs for a 30-calendar day liquidity stress scenario. This 30-day window buffer gives banks, supervisors and central banks a sufficient amount of time to implement any corrective action needed to restore liquidity and refurbish a stable business environment. Liquid capital provisions may be useful for managing bank runs and address deleveraging processes by banks with excessive risk-taking activity and/or with a severe borrowers' insolvency, as we experienced during the recent financial crisis. An over leveraged financial institution, which is suddenly exposed to an erosion in its asset quality, would incur extremely high costs when more capital is raised to offset the losses. By detaining a buffer of liquidity reserves, the bank can cope with a short-term illiquidity phase derived from the losses without raising new — expensive — equity.

In this study, we focus on cash and other marketable short-term assets as a proxy for liquidity buffer and we investigate how these assets relate to other risk measure in a dataset that spans from January 2005 to December 2014.

\footnotetext{
a Basel Committee on Banking Supervision. 2013, Basel III: "The Liquidity Coverage Ratio and liquidity risk monitoring tools". Bank for International Settlements, https://www.bis.org/publ/bcbs238.pdf.
} 
The dataset comprehends quarterly observation for 50 financial institutions belonging to STOXX Global 1800 Banks Index (mainly from United States, United Kingdom and Eurozone) for a total of approximately 1,800 observations.

The dataset precedes the definition and the implementation of the LCR, hence the ratio of cash and other marketable short-term securities on total assets $\left(\frac{\operatorname{cash}_{i, t}+S T \text { assets }_{i, t}}{\operatorname{assets}_{i, t}}\right)$ is preferred as liquidity buffer definition. Furthermore, LCR numeraire, which represents net cash outflow over the following 30 days under stress test hypothesis, requires further assumptions on the economic scenario and as well as from the national authorities that might not be homogenous across countries and time. By relying on our definition of liquidity buffer, we have a measure independent from (i) economic scenario assumptions (ii) Basel Committee assumptions (iii) national authorities' assumptions. More simply, LCR addresses liquidity crisis when it is already started while our liquidity provision measure works all year around and allows to capture the relationship with credit risk measures market-based variables, independently from the status of health of the financial sector.

Following Cornett et al. (2011), we focued our attention on how credit risk and market-based volatility measures influence changes in banks' liquidity provisions and changes in lending activity. We also broadened geographically the sample by relying on a dataset composed by local and global systematically important financial institution (G-SIFI) ${ }^{\mathrm{b}}$ rather than solely US-based banks. Cornett et al. (2011) focused on the main features that produce changes in liquidity provision and lending activity and discover that banks relying more on stable sources of financing, such as core deposit and equity capital financing, continued to lend relative to other banks with a less stable source of financing. Also, they found out that banks with more illiquid assets on their balance sheets increased their asset liquidity and reduced lending in the next quarter in order to balance out their asset structure and increase their liquidity provision.

We restate their model by introducing loan loss reserves on total asset ratio as a new exogenous variable and easy to compute credit risk measure in explaining liquidity provision and lending activity.

More importantly, we investigate how the liquidity ratio is influenced by marketbased volatility risk measures such as:

— options implied volatility skew, which captures trader's expectations about bank's idiosyncratic features;

— realized volatility on three months' LIBOR futures, which reflects the general macroeconomic environment.

\footnotetext{
b On November 2011, the Financial Stability Board published a list of 29 systematically important financial institutions describing them as "financial institutions whose distress or disorderly failure, because of their size, complexity and systemic interconnectedness, would cause significant disruption to the wider financial system and economic activity" or colloquially referred to as "too big to fail". Financial Stability Board 2011. "Policy Measures to Address Systematically Important Financial Institutions". Financial Stability Board, http://www.fsb.org/wp-content/uploads/r_111104bb.pdf.
} 
We expect a negative correlation between options implied volatility skew and liquidity provisions during times of financial distress as informed traders discount in their implied volatility prices any expected dry out of liquidity. We also expect a negative correlation between realized volatility on LIBOR and liquidity provision as liquidity dries up as there are major chances in liquidity mismatches during times of high volatility on interest rates.

If these market-based risk measures do influence banks' liquidity then they are eligible to play a role in a broader market discipline-based monitoring activity regarding the required liquidity provisions. Regulators might screen for implied volatility skew in banks in order to assess whether their liquidity provisions are at risk or not. Options-based risk measures deliver several advantages with respect to accounting measures. First of all, they are forward looking measures based on traders' expectations about equity future prices rather than accounting-based measures which are backward looking and lagged indicators. Second, options prices are computed at much higher frequencies than traditional measures hence they adapt to changing market conditions quickly and can help delivering informational content about banks' capital structure. Third, by selecting different types of options and moneyness levels, one can detect different kinds of risks. Finally, options market is a suitable environment for informed traders thanks to the high use of leverage, the asymmetric payoff and no constraint in short selling.

As a robustness check on the efficiency of these market-based risk measures, we also implemented a regression analysis having as a dependent variable bank's $z$-score, which is already identified by previous literature as a good risk measure to examine the effects of the financial assistance on banks' risk-taking behavior and we perform a split-sample analysis on the main models.

This paper is organized as follows: Section 1 is the introduction, Sec. 2 presents previous literature related to the topic, Sec. 3 describes the data and the methodology used in the analysis, Sec. 4 illustrates the results and robustness check analysis and Sec. 5 concludes.

\section{Previous Literature}

Previous literature analyzes the importance of liquidity provisions and loan loss reserves as viable tools for banks' stability. They also focus on the link between liquidity provisions and loan growth. Liquidity reserves, whether they are expressed in terms of cash or in terms of committed loan loss reserves, are capable of compensating capital adequacy ratio shortcomings as well as a proper prudential item to prevent financial distress.

On the other hand, options implied volatility measures proof their reliability in predicting an increase in equity risk.

Our goal is to link previous literature findings and investigate whether marketbased volatility measures (such as options implied volatility and LIBOR rate realized volatility) and balance sheet measures (such as loan loss reserves ratio) help explain changes in liquidity provision. 
An introduction on the behavior of loans activity and banks' liquidity creation was proposed by Diamond \& Rajan (2000) who presented a model where bank's liquidity on the asset side is tied together with its capital on the liability side. They state that greater bank capital reduces liquidity creation but enables the bank to survive and avoid distress. They also highlight that mixed capital optimizes bank's capital structure and banks with different capital sources extract different repayments from borrowers, resulting in an optimal bank capital structure that trades off the effects of bank capital on liquidity creation, the expected costs of bank distress, and the ease of forcing borrower repayment.

On loan growth, liquidity provisions and what happened during periods of financial distress, Ivashina \& Scharfstein (2010) showed that new loans to large borrowers fell by $47 \%$ during the peak period of the Financial Crisis relative to the prior three-month period and by $79 \%$ relative to the peak of the credit boom. Their goal is to understand the effect of the banking panic on the supply side of the credit to the corporate sector. By examining dataset on syndicated loans, they find out that, during the Financial Crisis, there was a simultaneous run by borrowers who drew down their credit lines, leading to a spike in commercial and industrial loans reported on bank balance sheets. They examine whether these stresses on bank liquidity led banks to cut lending. They find that banks cut their lending less if they had better access to deposit financing and thus they were not as reliant on short-term debt. With their model, they strengthen the existence of a link between bank liquidity provisions, new loan approvals and the stability of banks' financing, further supporting the role of liquidity provision for optimizing bank lending activity and stability.

Calomiris (2012) introduced the relevance of liquidity as a prudential tool and states that cash reserve requirements could play a role of broader prudential tool rather than just for addressing liquidity risk. However, when designing liquidity requirements for achieving a prudential goal of limiting bank default risk, regulators should consider trade-offs among capital requirements and liquidity requirements. The author, in examining the optimal combination of cash and capital requirements to deliver the lowest default risk for banks without compromising the loan supply for the economic growth, identifies four kinds of "frictions" that favor the use of liquidity requirements with respect to capital requirements: (1) the physical costs of liquidating assets when the bank is in need of new cash, (2) the adverse-selection costs associated with raising equity (which take the form of the discounting of equity offering upon announcement of the offering), (3) the limited verifiability of loan outcomes, which may compromise capital in the future due to bad outcome in the loan portfolio (whereas cash can provide a more transparent buffer against loss) and (4) the prospect of changes in the risk environment, which favors cash since it creates greater options value, making it less costly to adjust to changing in loan risk or in illiquidity risk.

Mortal \& Reisel (2013) evidenced that holding cash as a precautionary measure, rather than just a tool for managing illiquidity risk, is optimal for non-financial firms as well. 
The relationship between capital requirements, loan activity and liquidity provision is further explored by Thakor (2014) who reviewed theoretical and empirical literature in order to answer, among other issues, whether higher capital levels in banking lead to lower lending and liquidity creation by banks.

From a theoretical standpoint, two different views nourish the debate. One says that higher capital improves banks' incentives to make efficient asset portfolio choices and strengthens their incentives to monitor borrowers, and from this standpoint higher-capital banks are associated with more lending and liquidity creation, as well as higher bank values. The other standpoint says that higher capital may either directly reduce banks' liquidity and transaction services or lead to less efficient contracting resolutions and higher agency costs, thereby leading to lower liquidity creation by banks. ${ }^{\mathrm{c}}$

On an empirical basis, the paper highlights, in a cross-section analysis on banks, that higher capital is associated with higher lending activity, higher liquidity creation and higher probability of surviving the crisis. On the other hand, lower capital in banking leads to higher systemic risk and a higher probability of a governmentfunded bailout.

The research on the importance of liquidity as a prudential tool was further carried on by Calomiris et al. (2015) who investigated cash reserve requirements and strengthened the importance of bank liquidity requirements, in order to cope with liquidity risk during the time of financial distress as well as to prevent it. They argue that, while during the stable period just the deposit insurance may be optimal, in a model with multiple banks subject to liquidity shocks, an interbank market works as long as the group of banks imposes a cash requirement to prevent free riding on interbank liquidity assistance.

Mandatory capital requirements provide capital buffer to absorb losses on banks' balance sheets and to limit risk taking in the banking sector, but their restoration could be painful to achieve for a bank which faces high costs for raising new capital. This limitation could be amended, rather than from an increase in equity, by holding more liquid assets. They introduce a model of liquidity requirements that works as a prudential tool to make crisis less likely, where the focus of regulation is on the asset side of the bank's balance sheet and in which the liquidity requirement takes the form of a narrow cash reserve requirement rather than the Basel III approach, which seeks to limit the rollover risk. The paper evidences that cash is both observable and riskless and greater cash holdings improve bank incentives to manage risk in the remaining, non-cash portfolio of risky assets. Cash holdings reduce also the probability of a liquidity crisis by making the banking system more resilient from a default risk perspective.

On capital regulation optimization and the implementation of market-based measures, Berger et al. (1995) investigated the role of capital for financial institutions and how market-generated capital requirements differ from regulatory requirements,

c See Diamond \& Rajan (2001). 
while Santos (2001) reviewed the literature on the design of the financial system and bank capital regulation by presenting a list of the market failures that justify banking regulation. Barth et al. (2005), Berger et al. (2008) and Brewer et al. (2008) observed that bank capital's levels are higher than what regulation dictates thus opening up discussions about what determines this buffers, while Brunnermeier et al. (2008) proposed some distinctions between regulatory and market-based capital. On nonbinding capital requirements and banks' capital structure flexibility, see Flannery (1994), Myers \& Rajan (1998), Diamond \& Rajan (2000) and Allen et al. (2011). On the other hand, Flannery \& Nikolova (2004) and Gropp (2004) offered a survey on non-binding capital requirements in a market discipline framework.

On the relevance of new credit risk measures to be implemented in a capital adequacy framework, Chernykh \& Cole (2014) tested the predictive power of several alternative measures of bank capital adequacy in identifying US bank failures during the recent crisis period. They found that the non-performing asset coverage ratio (NPACR) significantly outperforms Basel-based ratios, including Tier 1 ratio, the Total Capital Ratio and the Leverage ratio, throughout the crisis period by accounting for both banking risks and asset quality. NPACR also aligns capital and credit risk, eliminates banking management incentives to mask capital deficiency and allows to account for various time period and cross-country provisioning rules. Their measure explicitly accounts for the capital-constrained banks' reluctance to build up adequate reserves for anticipated future loan losses and for regulators' forbearance in enforcing loan-loss reserving requirements. NPACR ratio is described as follows: $\mathrm{NPACR}_{i}=\frac{\text { equity }_{i}+\text { loan loss reserves }_{i}-\mathrm{NPL}_{i}}{\text { total assets }_{i}}$, or total equity plus loan-loss reserves less nonperforming assets, all divided by total assets. Compared to their model, our credit risk measure focuses only on loan loss reserves, and does not include non-performing assets and neglects equity because capital adequacy ratios, by themselves, are not part of our analysis, rather the role of liquidity provision is in a more complete capital adequacy framework. Capitalizing on their findings, we investigate whether loan loss reserve ratio is related to liquidity provision and lending activity.

Regarding the effectiveness of implied volatility risk measure, among all, Bates (1991) stated that the set of index call and put options prices across different moneyness levels gives a direct indication of market participants' aggregate subjective distribution of future price realizations. Therefore, out-of-the-money (OTM) puts become more expensive compared to at-the-money (ATM) calls and volatility skew increases before big negative jumps in price levels. In his paper, he shows that OTM puts became unusually expensive during the year preceding the $1987 \mathrm{crash}$ and by setting a model for pricing American-type option on jump-diffusion processes with systematic jump risk he shows that jump-diffusion parameters implicit in options prices indicate a crash was expected and that implicit distributions were negatively skewed in the year preceding 1987.

Borochin \& Yang (2014) analyzed the relationship between options implied volatility measure and capital structure for non-financial firms. They state that 
options implied volatility is a good proxy for cash flow risk and as the latter grows, the likelihood of a firm entering in default also increases, producing a rise in the cost of debt and ultimately a decrease in firm's leverage. They also use forward looking risk estimates impounded into options prices to create market-based indices which explain the ability to change firm's capital structure more than traditional accounting-based measures.

Capitalizing on previous literature findings we investigate whether option implied volatility is a good proxy for liquidity provisions dries up.

\section{Data and Methodology}

We built the dataset starting from quarterly observations of banks belonging to STOXX Global 1800 Banks Index. Among the 111 components of the Index, we selected those with quoted implied volatility on options during the considered timeframe. ${ }^{\mathrm{d}}$ The resulting dataset comprehends quarterly observations on 50 banks ${ }^{\mathrm{e}}$ for a total of approximately 1,800 observations from January 2005 to December 2014. Regarding the market-based data, for each bank, we collected options data for different moneyness level and different maturities. For moneyness levels (strike-tospot ratio), we selected call and put options from 0.80 to 1.20 and for maturities we chose options lasting from 3 months to 12 months. Call and put options with moneyness close to 1 were defined as the ATM option, call (put) with moneyness above 1.10 (below 0.90) was defined as the OTM. The approach in selecting ATM and OTM moneyness levels was consistent with Ofek et al. (2004).

Volatility skew is the difference between OTM put and ATM call options implied volatility and measures the excess premium paid for purchasing OTM put option with respect to ATM call option. All variables are obtained from Bloomberg database and the dataset has been cleansed and variables are organized as follows:

— balance sheet variables are normalized on total assets, or, expressed in 2010q1 constant US Dollar, in order to permit comparison;

— market-based variables are expressed in percentage points.

In order to capture how banks adjust their liquidity provisions and their lending activity in the next quarter, we select changes in liquid assets and loan activity standardized by bank's total assets as dependant variables, the ratio between loan loss reserves and total assets as the main exogenous variable of study and illiquid assets, equity and the logarithm of total assets as control exogenous variables. In addition, the interaction between exogenous variables and TED spread allows us to see how liquidity provisions and lending activity changes when inter-banking market is under stress. Equation (1) describes the model to capture the relationship between

\footnotetext{
d Among those with quoted implied volatility, we further shrink the sample by relying only on those with at least half of the considered timeframe ( 60 months) of active daily quotes on options' implied volatility. e Table A.1 reports the 50 selected financial institutions.
} 
changes in liquidity provisions and changes in the proposed credit risk measure.

$$
\begin{aligned}
\frac{\Delta \operatorname{liquid}_{i, t}}{\operatorname{assets}_{i, t-1}}= & \beta_{0}+\beta_{1} \frac{\text { illiquid }_{i, t-1}}{\operatorname{assets}_{i, t-1}}+\beta_{2} \frac{\text { illiquid }_{i, t-1}}{\operatorname{assets}_{i, t-1}} * \operatorname{TED}_{i, t-1}+\beta_{3} \operatorname{creditrisk}_{i, t-1} \\
& +\beta_{4} \operatorname{creditrisk}_{i, t-1, t} * \operatorname{TED}_{i, t-1}+\beta_{5} \frac{\text { equity }_{i, t-1}}{\operatorname{assets}_{i, t-1}}+\beta_{6} \frac{\text { equity }_{i, t-1}}{\operatorname{assets}_{i, t-1}} * \operatorname{TED}_{i, t-1} \\
& +\beta_{5} \mathbf{X}_{t}+\varepsilon_{i, t},
\end{aligned}
$$

where, as liquid assets, we use cash and short-term marketable securities, and as illiquid assets we use long-term investments, creditrisk $_{i, t-1}$ is given by the ratio between loan loss reserves and total assets, while $\mathrm{TED}_{i, t-1}$ is the difference between three months LIBOR and the three months treasury bills yield rate for bank $i$ at time $t-1$, which captures the stress on the interbank market. In Eq. (1), $\beta_{1}$ and $\beta_{3}$ tell us correspondingly how banks more exposed to illiquid assets and insolvencies adapt their liquidity holdings in the next quarter when the inter-banking activity is normal, while $\beta_{2}$ and $\beta_{4}$ allow us to study the role of these variables when the inter-banking market is under stress. $\beta_{5}$ and $\beta_{6}$ focus on how better capitalized banks adjust their liquidity needs.

Equation (2) describes the model to capture the relationship between changes in loan activity and changes in the proposed credit risk measure.

$$
\begin{aligned}
\frac{\Delta \text { loans }_{i, t}}{\operatorname{assets}_{i, t-1}}= & \beta_{0}+\beta_{1} \frac{\text { illiquid }_{i, t-1}}{\operatorname{assets}_{i, t-1}}+\beta_{2} \frac{\text { illiquid }_{i, t-1}}{\operatorname{assets}_{i, t-1}} * \operatorname{TED}_{i, t-1}+\beta_{3} \operatorname{creditrisk}_{i, t-1} \\
& +\beta_{4} \operatorname{creditrisk}_{i, t-1, t} * \operatorname{TED}_{i, t-1}+\beta_{5} \frac{\text { equity }_{i, t-1}}{\operatorname{assets}_{i, t-1}}+\beta_{6} \frac{\text { equity }_{i, t-1}}{\operatorname{assets}_{i, t-1}} * \operatorname{TED}_{i, t-1} \\
& +\beta_{5} \mathbf{X}_{t}+\boldsymbol{\varepsilon}_{i, t} .
\end{aligned}
$$

In Eq. (2), $\beta_{1}$ and $\beta_{3}$ tell us how banks more exposed to illiquid assets and insolvencies adapt their lending activity in the following quarter when the interbanking activity is normal, meanwhile $\beta_{2}$ and $\beta_{4}$ describe the role of these variables when the inter-banking market is under stress. $\beta_{5}$ and $\beta_{6}$ relate to how better capitalized banks adjust their next quarter lending activity.

On the other hand, when we address the effectiveness of market volatility measures in influencing future liquidity provisions and their usefulness in a marketdisciplined regulatory framework, we shift to levels for the dependant variable as presented in the general model in Eq. (3).

$$
\begin{aligned}
\operatorname{Liq}_{i, t}= & \beta_{0}+\beta_{1} \text { creditrisk }_{i, t-1}+\beta_{2} \text { creditrisk }_{i, t-1, t} * \operatorname{TED}_{i, t-1}+\beta_{3} \text { skew }_{i, t-1} \\
& +\beta_{4} R V_{\text {LIBOR }, t-1}^{c}+\beta_{5} \mathbf{X}_{t}+\varepsilon_{i, t}
\end{aligned}
$$

where $\operatorname{Liq}_{i, t}=\frac{\operatorname{liquid}_{i, t}}{\operatorname{assets}_{i, t}}$ represents the liquidity ratio for bank $i$, in quarter $t$, which is equal to the ratio between cash plus other short-term securities assets and bank's total asset, skew ${ }_{i, t-1}$ is the volatility skew and is equal to the difference between 
OTM put and ATM call options implied volatility. The volatility skew measures the over premium paid for purchasing OTM put option with respect to ATM call option. Equation (5) defines volatility skew.

$$
\text { skew }_{i, t}=i v_{i, t}^{\mathrm{ATM}, \text { call }}-i v_{i, t}^{\mathrm{OTM}, \text { put }}
$$

where $i v_{i, t}^{\mathrm{ATM} \text {,call }}$ is the implied volatility for ATM call option on stock $i$ at time $t$ and $i v_{i, t}^{\text {OTM,put }}$ is the implied volatility for an OTM put option, stock $i$ at time $t$.

$R V_{\mathrm{LIBOR}, t-1}^{c}=\sqrt{4} \sum_{j=1}^{60} r_{\mathrm{LIBOR}, j}^{2}$ is the realized volatility from daily log-returns for futures contract on three months LIBOR for country $c$ (whom bank $i$ belongs to) and quarter $t-1$. Realized volatility calculated from futures contract on interbank lending interest rate gives us several advantages in comparison to realized volatility on bank's $i$ stocks:

(i) it is not focused on bank's $i$ idiosyncratic risks but rather captures issues relating to the banking sector and macroeconomic aspects;

(ii) it is a forward looking measures and a direct expression of traders' sentiment on underlying LIBOR in three-months time, as being derived from quoted futures rather than from inter-banking dealers average rates. ${ }^{\mathrm{f}}$

Using options-based and futures-based risk measures to address changes in liquidity delivers several advantages with respect to accounting measures. First of all, they are forward looking measures based on traders' expectations on equity future prices rather than accounting-based measures which are backward looking and lagged indicators. Second, prices are computed at much higher frequencies than the traditional measures, hence they react quickly to changing market conditions and help in delivering informational content about banks' capital structure or about sudden fluctuations in macroeconomic environment. RV quickly absorbs any spikes in the quotation of the underlying market.

Also, options market is a suitable environment for informed traders thanks to the high use of leverage, the asymmetric payoff and no constraint in short selling. Options give the opportunity but not the obligation to buy or sell a specific asset at a specific price within — or at - a specific point in time. Traders operate in options market by quoting their implied volatilities for different maturities and moneyness according to their views on future stock's returns. The result of this trading activity produces volatility skews, smirks and spreads which get away from Black \& Scholes (1973) environment of constant volatility across all maturity and all moneyness.

As a robustness' check, we run the same model in Eq. (3) using as dependant variable bank's $z$-score which is a measure of stability. The $z$-score is the sum of the quarterly return-on-assets and equity-to-assets ratio, divided by the standard

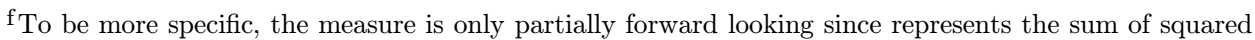
daily returns of the previous quarter instead a better forward looking measure would have been one based on implied volatility from option on LIBOR.
} 
deviation of the return on assets, see Roy (1952) to measure bank solvency. The $z$ score indicates the number of standard deviations that a bank's rate of return-onassets can fall in a single period before it becomes insolvent. A higher $z$-score signals a lower probability of bank insolvency.

Fixed effect regression analysis is performed on a panel dataset of 50 banks from 2005 to 2014 for a total of 1,800 quarterly observations for the models specified in Eqs. (1) and (2), and 1,300 quarterly observations for the model specified in Eq. (3). In order to cope with heteroskedasticity and serial correlation issues, we clustered standard errors at bank level as well as at quarterly level. We also implemented bank's fixed effects as suggested by Petersen (2009) and as applied by Cornett et al. (2011).

\section{Results}

Table 1 shows the descriptive statistics for the dataset describing the considered variables, Table 2 furtherly illustrate our major variables of interest before and after the Financial Crisis, while Table 3 depicts the correlation for the very same variables.

Table 3 reports correlation among market and balance sheet variables for banks.

Table 4 illustrates the results from Eqs. (1) and (2). As already stated by Petersen (2009), banks with more long-term investments are forced to build up their liquid assets both in periods of financial distress and in normal times. Better capitalized banks also increase their liquid assets. Banks with higher credit risk are forced to dismiss long-term securities and build up cash reserves only when we are in a period of inter-banking stress. Regarding new loan commitments, we can state that banks

Table 1. Descriptive statistics.

\begin{tabular}{lcccccrrr}
\hline & Obs & Mean & STD & Min & Max & 25th pct. & 50th pct. & 75th pct. \\
\hline Assets & 1,806 & 734.1 & 860.4 & 24.81 & 4,863 & 130.4 & 321.7 & $1,177.5$ \\
Loans & 1,806 & 0.575 & 0.228 & 0.091 & 0.860 & 0.431 & 0.601 & 0.693 \\
Cash & 1,806 & 0.027 & 0.031 & 0.000 & 0.302 & 0.007 & 0.016 & 0.033 \\
Cash + ST securities & 1,806 & 0.097 & 0.081 & 0.000 & 0.355 & 0.039 & 0.081 & 0.129 \\
LT investments & 1,806 & 0.077 & 0.134 & 0.001 & 0.377 & 0.001 & 0.015 & 0.085 \\
Deposits & 1,806 & 0.494 & 0.168 & 0.055 & 0.802 & 0.353 & 0.485 & 0.646 \\
Loan loss reserves & 1,806 & 0.014 & 0.013 & 0.001 & 0.126 & 0.005 & 0.011 & 0.017 \\
Total equity & 1,806 & 0.071 & 0.030 & 0.010 & 0.174 & 0.046 & 0.065 & 0.091 \\
Interbank assets & 1,806 & 0.060 & 0.057 & 0.005 & 0.272 & 0.022 & 0.046 & 0.087 \\
Skew & 1,342 & -6.714 & 4.303 & -33.789 & 9.844 & -9.398 & -7.137 & -4.414 \\
ROA & 1,806 & 0.555 & 0.8302 & -5.862 & 13.37 & 0.246 & 0.580 & 0.919 \\
ROA st. dev. & 1,667 & 0.260 & 0.379 & 0.006 & 5.352 & 0.079 & 0.144 & 0.290 \\
\hline
\end{tabular}

Notes: The dataset consists in quarterly observation on 50 publicly traded banks from STOXX GLOBAL 1800 Banks from 2005 to 2014. Assets are expressed in USD 2010q1 constant billions other balance sheet items are weighted over total assets. Skew, return-on-asset and return-on-asset standard deviation are expressed in percentage points. 
Table 2. Variables of interest pre and post crisis (2007q2-2009q1).

\begin{tabular}{|c|c|c|c|c|c|c|c|}
\hline & Mean & STD & Min & $\operatorname{Max}$ & 25 th pct. & 50 th pct. & 75th pct. \\
\hline \multicolumn{8}{|c|}{ Pre crisis } \\
\hline Assets & 468.0 & 558.3 & 28.4 & $2,453.0$ & 87.0 & 199.2 & 517.9 \\
\hline Loans & 0.009 & 0.008 & 0.000 & 0.047 & 0.004 & 0.007 & 0.012 \\
\hline Cash + ST securities & 0.582 & 0.268 & 0.108 & 1.971 & 0.436 & 0.568 & 0.699 \\
\hline Loan loss reserves & 0.094 & 0.065 & 0.000 & 0.288 & 0.037 & 0.089 & 0.130 \\
\hline Skew & -3.743 & 2.816 & -13.785 & 7.340 & -5.913 & -3.650 & -1.851 \\
\hline ROA & 0.987 & 0.469 & -0.113 & 2.686 & 0.661 & 0.903 & 1.247 \\
\hline \multicolumn{8}{|c|}{ Post crisis } \\
\hline Assets & 803.7 & 912.4 & 6.6 & $4,863.4$ & 175.3 & 365.3 & $1,225.5$ \\
\hline Loans & 0.017 & 0.018 & 0.001 & 0.343 & 0.005 & 0.012 & 0.021 \\
\hline Cash + ST securities & 0.577 & 0.485 & 0.145 & 15.741 & 0.434 & 0.598 & 0.676 \\
\hline Loan loss reserves & 0.101 & 0.090 & 0.000 & 1.955 & 0.043 & 0.081 & 0.144 \\
\hline Skew & -4.755 & 3.378 & -24.566 & 12.580 & -6.685 & -5.188 & -3.333 \\
\hline ROA & 0.337 & 0.686 & -5.862 & 1.648 & 0.125 & 0.404 & 0.725 \\
\hline
\end{tabular}

Notes: The table describes the descriptive statistics for the main variables of study in Eqs. (1)-(3). Assets are expressed in USD 2010q1 constant billions, other balance sheet items are weighted over total assets. Skew, return-on-asset and are expressed in percentage points.

with more illiquid investments tend to reduce their loan approvals in the next quarter when inter-banking market is working properly. We cannot infer the same thing during the period of financial stress. Better capitalized banks continue their lending activity without any trouble and higher credit risk levels force banks to

Table 3. Correlations.

\begin{tabular}{|c|c|c|c|c|c|c|c|c|}
\hline & $\begin{array}{l}\text { Liquidity } \\
\text { ratio }\end{array}$ & $\begin{array}{l}\text { Credit } \\
\text { risk }\end{array}$ & $z$-score & $\begin{array}{c}\text { equity-to-asset } \\
\text { ratio }\end{array}$ & TED & Skew & $\begin{array}{c}\mathrm{LT} \\
\text { invest }\end{array}$ & $\begin{array}{c}\text { Loan loss } \\
\text { reserves }\end{array}$ \\
\hline Liquidity ratio & 1.000 & & & & & & & \\
\hline Credit risk & $\begin{array}{c}0.208 \\
(0.001)\end{array}$ & 1.000 & & & & & & \\
\hline$z$-score & $\begin{array}{c}0.082 \\
(0.001)\end{array}$ & $\begin{array}{r}-0.257 \\
(0.001)\end{array}$ & 1.000 & & & & & \\
\hline $\begin{array}{l}\text { Equity-to-asset } \\
\text { ratio }\end{array}$ & $\begin{array}{c}0.311 \\
(0.0000)\end{array}$ & $\begin{array}{c}0.558 \\
(0.0000)\end{array}$ & $\begin{array}{r}-0.026 \\
(0.970)\end{array}$ & 1.000 & & & & \\
\hline TED & $\begin{array}{r}-0.008 \\
(0.097)\end{array}$ & $\begin{array}{r}-0.067 \\
(0.360)\end{array}$ & $\begin{array}{r}-0.130 \\
(0.000)\end{array}$ & $\begin{array}{c}0.013 \\
(0.713)\end{array}$ & 1.000 & & & \\
\hline Skew & $\begin{array}{r}-0.091 \\
(0.046)\end{array}$ & $\begin{array}{c}0.004 \\
(0.503)\end{array}$ & $\begin{array}{r}-0.047 \\
(0.572)\end{array}$ & $\begin{array}{c}-0.021 \\
(0.987)\end{array}$ & $\begin{array}{c}-0.033 \\
(0.003)\end{array}$ & 1.000 & & \\
\hline LT investment & $\begin{array}{c}0.293 \\
(0.005)\end{array}$ & $\begin{array}{c}0.387 \\
(0.000)\end{array}$ & $\begin{array}{c}-0.094 \\
(0.039)\end{array}$ & $\begin{array}{c}0.581 \\
(0.000)\end{array}$ & $\begin{array}{c}0.039 \\
(0.805)\end{array}$ & $\begin{array}{c}0.240 \\
(0.000)\end{array}$ & 1.000 & \\
\hline Loan loss reserves & $\begin{array}{c}0.208 \\
(0.001)\end{array}$ & $\begin{array}{c}1.000 \\
(0.000)\end{array}$ & $\begin{array}{r}-0.257 \\
(0.000)\end{array}$ & $\begin{array}{c}0.558 \\
(0.000)\end{array}$ & $\begin{array}{r}-0.067 \\
(0.360)\end{array}$ & $\begin{array}{c}0.004 \\
(0.503)\end{array}$ & $\begin{array}{c}0.387 \\
(0.000)\end{array}$ & 1.000 \\
\hline
\end{tabular}

Notes: The dataset consists in quarterly observation on 50 publicly traded banks from STOXX GLOBAL 1800 Banks from 2005 to 2014 . The $p$-value of the coefficients is provided within brackets. 
Table 4. Addressing credit risk measure effects for liquidity and loans.

\begin{tabular}{lcc}
\hline & $(1)$ & $(2)$ \\
\hline Numeraire: assets $(t-1)$ & Dliquidassets/assets $(t-1)$ & $\Delta$ loans/assets $(t-1)$ \\
Illiquid assets $(t-1)$ & 0.5843 & -0.1298 \\
& $\mathbf{2 . 7 9}$ & $\mathbf{- 2 . 8 9}$ \\
Illiquid assets*TED $(t-1)$ & 0.2913 & -0.0596 \\
& $\mathbf{2 . 4 4}$ & -1.25 \\
Capital $(t-1)$ & 1.4432 & 0.4176 \\
& $\mathbf{2 . 2 2}$ & $\mathbf{3 . 7 3}$ \\
Capital*TED $(t-1)$ & -0.1984 & 0.2256 \\
& -0.54 & 1.33 \\
Credit risk $(t-1)$ & 0.7705 & -0.5628 \\
& 1.07 & $\mathbf{- 3 . 4 1}$ \\
Credit risk*TED $(t-1)$ & 4.0917 & -0.4835 \\
Log(Assets) $(t-1)$ & $\mathbf{3 . 6 4}$ & -1.48 \\
& 0.0393 & -0.01627 \\
Log(Assets)*TED $(t-1)$ & 1.28 & $-\mathbf{4 . 1 7}$ \\
& -0.003 & -0.0029 \\
$R$-squared & -1.92 & -1.09 \\
-statistic & 0.48 & 0.09 \\
\hline
\end{tabular}

Notes: This table shows the main results from regression analysis of Eqs. (1) and (2). The model measures the effect of credit risk (measured as the ratio between loan loss reserves and total assets) on changes in next quarter banks' liquid assets in model (1) and in new loans in model (2). The dataset consists in quarterly observation on 50 publicly traded banks from STOXX GLOBAL 1800 Banks from 2005 to 2014 for a total of approximately 1,800 observations. In order to deal with heteroskedaticity and serial correlation issues standard errors are clustered at bank's level. Balance sheet items are weighted over total assets at $t-1$. Bold figures represent coefficients statistically significant at a 5 or below percent level.

reduce the amount of lending. We run a robustness' check implementing Eq. (1) on five different sub-samples, results are shown in the following subsection.

Table 5 focuses on the effect of credit risk and market risk measures on bank's overall liquidity ratio as presented in Eq. (3). As a robustness' check in model (5), we use as variable of interest the $z$-score and we also run the same model of Eq. (3) on three different subsection. Results on the split-sample analysis are shown in the next subchapter. Regarding overall liquidity during the period of financial stability, high levels of loan loss reserves do not immediately bind the bank to provide new cash in order to increase liquidity provisions; actually the bank decreases its liquidity ratio since it is not under pressure from either depositors, investors or other financial intermediaries. But, when tough times come, over exposure to loan losses forces the bank to liquidate other assets and replenish its liquidity provisions. Skew measures traders' expectation on the downward movement on bank's stock which is negatively related with liquidity ratio. As the bank is expected to suffer from liquidity vanishing, traders expect a drop in stock's prices, hence OTM put option became severely more expensive than the ATM call. Finally, LIBOR-realized volatility 
Table 5. Credit risk and market volatility risk measure.

\begin{tabular}{lcccc}
\hline all lagged at $(t-1)$ & $(3)$ & $(4)$ & $(5)$ & $(6)$ \\
\hline Credit risk & $-0,7109$ & & $-2,2258$ & \\
& $\mathbf{- 3 , 5}$ & & $-\mathbf{3 , 4 1}$ & \\
Credit risk*TED & 0,602 & & $-0,7833$ & \\
& $\mathbf{2 , 6 5}$ & & $-1,63$ & \\
Skew & $-0,0011$ & $-0,001$ & $-0,227$ & \\
& $\mathbf{- 2 , 1 1}$ & $-1,83$ & $-1,64$ & $-0,2196$ \\
LIBOR RV & $-0,013$ & $-0,0095$ & $-1,5232$ & $\mathbf{- 1 , 9 6}$ \\
& $\mathbf{- 3 , 6 6}$ & $-\mathbf{2 , 1 6}$ & $\mathbf{- 2 , 9 1}$ & $-2,604$ \\
Leverage & 0,5027 & & 1,6074 & $\mathbf{- 3 , 5 1}$ \\
& $\mathbf{2 , 0 7}$ & & $\mathbf{4 , 3}$ & \\
Leverage*TED & 0,056 & & $-0,8614$ & \\
& 0,46 & & $\mathbf{2 , 7 1}$ & \\
Log(Assets) & 0,0379 & & 0,0081 & \\
& $\mathbf{2 , 1 9}$ & & 1,84 & \\
Log(Assets)*TED & $-0,001$ & & 0,0001 & \\
& $-1,36$ & & 0,83 & \\
$R$-squared & 0,13 & 0,09 & 0,16 & 0,04 \\
$F$-statistic & 4,55 & 4,00 & 3,84 & 4,33 \\
\hline
\end{tabular}

Notes: This table shows the main results from regression analysis of Eq. (3). The model measures the effect of credit risk (measured as the ratio between loan loss reserves and total assets), volatility skew derived from options on bank's stock and realized volatility from quotes on Libor three months futures on bank's liquid ratio (which is given by the cash and short-term securities divided by total assets) in model (3) and (4) and on bank's z-score (given by the sum of ROA and equity-to-asset ratio standardized by ROA standard deviation) in model (5) and (6). As control variables we identified equity-to-asset ratio and $\log$ (Assets). The dataset consists of quarterly observation on 50 publicly traded financial institutions from STOXX GLOBAL 1800 Banks from 2005 to 2014 for a total of approximately 1,300 observations. In order to deal with heteroskedaticity and serial correlation issues standard errors are clustered at bank's level. Bold figures represent coefficients statistically significant at a 5 or below percent level.

captures distress in inter-banking market and hence is negatively related to liquidity ratio.

\subsection{Robustness check and limitations}

In the robustness check analysis, we implemented the model expressed in Eq. (1) on five specific sub-samples of the main dataset and for Eq. (3) for three specific subsamples. For Eq. (1), three of the five are time specific sub-samples (i) after 2009q1, which captures the behavior after the Financial Crisis, (ii) from 2007q2 to 2009q1, which captures the behavior during the Financial Crisis and (iii) before 2007q2 and after 2009q1, in order to observe the variables in the absence of the Financial Crisis. The remaining two sub-samples are size specific (iv) the smallest half of the sample 
and (v) the largest half of the sample according to total assets. Table 6 presents the results. Our split sample analysis supports our main finding that banks with higher credit risk are forced to dismiss long-term securities and build up cash reserves only when we are in a period of inter-banking stress and only for the smallest $50 \%$ of the sample.

A first robustness' check on Eq. (3) is performed by changing the variable of interest. We substitute bank's liquidity with bank's z-score and performed the analysis on the full sample. Results are shown in Table 5, model (5) and (6). For Eq. (3), we also perform a split-sample analysis. Due to a smaller number of observations available, we relied only on three sub-samples: one time specific (i) that covers before $2007 \mathrm{q} 2$ and after $2009 \mathrm{q} 1$, in order to observe the variables in the absence of the Financial Crisis and two-size specific to capture the behavior among (ii) the smallest half of the sample and (iii) the largest half of the sample according to total assets and Table 7 present the results. Our split sample analysis supports our main finding that high levels of loan loss reserves do not immediately bind the bank to provide new cash in order to increase liquidity provisions, actually the bank decreases their liquidity ratio since it is not under pressure. But, during period of

Table 6. Equation (1) split sample analysis.

\begin{tabular}{lclllc}
\hline & Post crisis & Crisis & Ex. crisis & Smallest 50\% & Largest 50\% \\
\hline numeraire: assets $(t-1)$ & & & & & \\
Illiquid assets $(t-1)$ & 0.0696 & -0.0502 & 0.0429 & 0.1063 & 0.0422 \\
& $\mathbf{3 . 9 2}$ & -1.29 & $\mathbf{2 . 9 7}$ & $\mathbf{6 . 7 9}$ & 1.55 \\
Illiquid assets*TED $(t-1)$ & -0.0055 & -0.0004 & 0.0173 & 0.0050 & -0.013 \\
& -0.35 & -0.04 & 1.22 & 0.54 & -0.77 \\
Capital $(t-1)$ & -0.4819 & -0.2727 & -1.684 & -1.171 & 0.8013 \\
& $\mathbf{- 4 . 5 8}$ & -0.77 & -1.74 & -1.44 & 0.52 \\
Capital*TED $(t-1)$ & -0.0262 & 0.1099 & -0.2561 & 0.0689 & 0.1142 \\
& -0.61 & 1.56 & -0.57 & 1.86 & 1.48 \\
Credit risk $(t-1)$ & 0.0195 & -0.4854 & -0.0511 & 0.0050 & 0.1619 \\
& 0.24 & -0.57 & -0.57 & 0.54 & 0.48 \\
Credit risk*TED $(t-1)$ & 4.62 & 3.18 & 5.31 & 2.84 & -5.01 \\
& $\mathbf{3 . 2 9}$ & $\mathbf{1 . 9 8}$ & $\mathbf{3 . 5 0}$ & $\mathbf{3 . 9 9}$ & -0.16 \\
Log(Assets) $(t-1)$ & -0.0153 & -0.2849 & -0.0006 & -0.0117 & -0.0064 \\
& $\mathbf{- 2 . 1 3}$ & -1.68 & -0.18 & $-\mathbf{2 . 5 9}$ & -1.36 \\
Log(Assets)*TED $(t-1)$ & -0.0004 & 0.0002 & -0.0003 & -0.0001 & 0 \\
& $\mathbf{- 1 . 9 9}$ & 0.84 & -1.62 & -0.48 & -0.16 \\
$R$-squared & 0.238 & 0.0814 & 0.2144 & 0.3578 & 0.058 \\
$F$-statistic & 8.57 & 1.93 & 5.42 & 10.91 & 2.81 \\
Obs. & 1,147 & 352 & 1,454 & 862 & 944 \\
\hline & & & & &
\end{tabular}

Notes: This table shows the main results from regression analysis of Eq. (1). The model measures the effect of credit risk (measured as the ratio between loan loss reserves and total assets) on changes in next quarter banks' liquid assets in model (1). The dataset consists in quarterly observation on 50 publicly traded banks from STOXX GLOBAL 1800 Banks from 2005 to 2014 for a total of approximately 1,800 observations. In order to deal with heteroskedaticity and serial correlation issues, standard errors are clustered at bank's level. Balance sheet items are weighted over total assets at $t-1$. Bold figures represent coefficients statistically significant at a 5 or below percent level. 
Table 7. Equation (2) split sample analysis.

\begin{tabular}{lccc}
\hline all lagged at $(t-1)$ & Ex. crisis & Smallest 50\% & Largest 50\% \\
\hline Credit risk & $-0,8706$ & $-0,4641$ & $-2,02$ \\
& $\mathbf{- 3 , 1 7}$ & $\mathbf{- 2 , 2}$ & $-\mathbf{2 , 8 4}$ \\
Credit risk*TED & 0,828 & 0,956 & $-1,0971$ \\
& $\mathbf{3 , 0 6}$ & $\mathbf{3 , 6 9}$ & $-1,57$ \\
Skew & $-0,0009$ & $-0,007$ & 0,0006 \\
& $\mathbf{- 1 , 9 8}$ & $-1,91$ & 0,98 \\
LIBOR RV & $-0,0027$ & $-0,0001$ & $-0,0001$ \\
& $\mathbf{- 2 , 1 1}$ & $\mathbf{- 2 , 3 4}$ & $-0,12$ \\
Leverage & 0,19 & $-0,2565$ & 0,8183 \\
& 0,78 & $-1,67$ & 1,26 \\
Leverage*TED & $-0,1157$ & $-0,02744$ & $-0,0924$ \\
& $-1,46$ & $-0,44$ & $-0,68$ \\
Log(Assets) & 0,04309 & 0,007 & 0,06215 \\
& $\mathbf{2 , 3 7}$ & 0,45 & 1,77 \\
Log(Assets)*TED & $-0,0017$ & $-0,0003$ & 0,0001 \\
& $\mathbf{- 2 , 0 2}$ & $-0,73$ & 0,27 \\
$R$-squared & 0,17 & 0,28 & 0,07 \\
$F$-statistic & 2,38 & 3,67 & 2,7 \\
Obs. & 936 & 545 & 545 \\
\hline
\end{tabular}

Notes: This table shows the main results from regression analysis of Eq. (3). The model measures the effect of credit risk (measured as the ratio between loan loss reserves and total assets), volatility skew derived from options on bank's stock and realized volatility from quotes on Libor 3 months futures on bank's liquid ratio (which is given by the cash and short-term securities divided by total assets). As control variables we identified equity-to-asset ratio and $\log$ (Assets). The dataset consists in quarterly observation on 50 publicly traded financial institutions from STOXX GLOBAL 1800 Banks from 2005 to 2014 for a total of approximately 1,300 observations. In order to deal with heteroskedaticity and serial correlation issues, standard errors are clustered at bank's level. Bold figures represent coefficients statistically significant at a 5 or below percent level.

financial distress exposure to loan losses forces the bank to liquidate other assets and replenish its liquidity provisions. Regarding LIBOR-realized volatility, its negative relationship with liquidity ratio is relevant only for the smallest half of the sample.

Among the limitation of the study it is worth noting that we did not check for endogeneity of the explanatory variables. Although we rely only on lagged variables and we excluded any form of autoregressive model we cannot conclude that the correlation between the explanatory variables and the error term is absent. A further analysis would be required in order to properly verify this issue.

\section{Conclusions}

In this paper, we studied how credit risk measure interacts with changes in liquidity provisions and new loans are committed during the period of financial stability and 
financial distress. Losses from lending activity force banks to build up new liquidity provisions only during the period of financial distress and cripple lending activity during the period of financial stability and in particular for small banks. Looking at the overall bank's liquidity ratio in addition to credit risk measure, we implemented market-based risk measures such as the implied volatility skew from options and the realized volatility from LIBOR three-months futures. These two measures enable us to capture market-based risk about bank's idiosyncratic features (with volatility skew) and macroeconomic environment (with realized volatility on LIBOR). We discovered that credit risk reduces the liquidity ratio during stable times and does not trigger any liquid asset demand from banks. On the other hand, when we experience periods of severe financial distress, this demand for liquid asset is suddenly switched on and the more reserves from loan losses the bank has, the more it cleans its balance sheet from long-term commitments in order to replenish its cash and short-term securities. Implied volatility skew is negatively related with liquidity ration and predicts a distress in bank's liquidity holdings as traders' future expectations are translated in OTM put options prices. Realized volatility on futures contract on 3 months LIBOR is also useful in predicting reduction in liquidity holdings. When we study whether these market-based variables influence bank's $z$-score, we find results in line with what we expected. Skew and LIBOR-realized volatility compromise bank's stability. Our paper evidences that it might be of help for regulators to implement market-based volatility measures when they set up liquidity provision requirements for banks and other financial institutions as implied volatility measure offers a forward-looking expectation of informed traders. As liquidity provision requirements work as a prudential tool in the worsening of bank's financial stability and the prevention of a financial crisis, a market-based forward-looking volatility measure would increase the effectiveness of the provision requirement.

\section{Appendix A}

Table A.1. List of the 50 financial institutions in the dataset.

\begin{tabular}{lc}
\hline Name & Country \\
\hline Erste Group Bank AG & Austria \\
Raiffeisen Bank International AG & Austria \\
KBC Group NV & Belgium \\
Canadian Imperial Bank of Commerce & Canada \\
National Bank of Canada & Canada \\
Royal Bank of Canada & Canada \\
Toronto-Dominion Bank & Canada \\
BNP Paribas SA* & France \\
Societe Generale SA* & France \\
Commerzbank AG* & Germany \\
\hline
\end{tabular}


Table A.1. (Continued)

\begin{tabular}{|c|c|}
\hline Name & Country \\
\hline Deutsche Bank AG* & Germany \\
\hline Banca Monte dei Paschi di Siena SpA & Italy \\
\hline Banca Popolare di Sondrio SCPA & Italy \\
\hline Banca Popolare di Milano Scarl & Italy \\
\hline BPER Banca S.p.A. & Italy \\
\hline Intesa Sanpaolo S.p.A. & Italy \\
\hline Mediobanca S.p.A. & Italy \\
\hline Unicredit S.p.A.* & Italy \\
\hline Unione di Banche Italiane S.p.A. & Italy \\
\hline Mitsubishi UFJ Financial Group Inc. & Japan \\
\hline Mizuho Financial Group Inc. & Japan \\
\hline Sumitono Mitsui Trust Holdings Inc.* & Japan \\
\hline DNB ASA & Norway \\
\hline Banco Bilbao Vizcaya Argentaria SA & Spain \\
\hline Banco de Sabadell SA & Spain \\
\hline Banco Popular Espanol SA & Spain \\
\hline Banco Santander SA* & Spain \\
\hline CaixaBank SA & Spain \\
\hline Nordea Bank AB & Sweden \\
\hline Scenska Handelsbanken AB & Sweden \\
\hline Skandinaviska Enskilda Banken AB & Sweden \\
\hline Swedbank AB & Sweden \\
\hline Credit Suisse Group AG* & Switzerland \\
\hline UBS AG* & Switzerland \\
\hline Barclays PLC* & UK \\
\hline HSBC Holdings PLC* & UK \\
\hline Lloyds Banking Group PLC* & UK \\
\hline Bank of America Corp. & USA \\
\hline BB\&T Corp. & USA \\
\hline Citigroup Inc.* & USA \\
\hline Comerica Inc. & USA \\
\hline Huntington Banshares Inc. & USA \\
\hline JPMorgan Chase \& Co.* & USA \\
\hline Key Corp. & USA \\
\hline M\&T Bank Corp. & USA \\
\hline PNC Financial Services Group Inc. & USA \\
\hline Regions Financial Corp. & USA \\
\hline SunTrust Banks Inc. & USA \\
\hline US Bancorp & USA \\
\hline Wells Fargo \& Co.* & USA \\
\hline
\end{tabular}

Notes: This table shows the list of the 50 financial institutions comprehended in the dataset. All the selected financial institutions belong to the STOXX Global 1800 Banks those with an asterisk after their name are also considered G-SIFI according to the list published by the Financial Stability Board in November 2011. 


\section{References}

F. E. Allen, Carletti \& R. Marquez (2011) Credit market competition and capital regulation, Review of Financial Studies 24, 983-1018.

Basel Committee on Banking Supervision (1992) Minimum standards for the supervision of international banking groups and their cross-border establishments. Bank for International Settlements.

Basel Committee on Banking Supervisions (2013). Basel III: The Liquidity Coverage Ratio and liquidity risk monitoring tools. Bank for International Settlements.

Bates, D (1991) The Crash of '87: Was it expected? The evidence from options markets, Journal of Finance 46, 1009-1044.

A. N. Berger, R. DeYoung, M. J. Flannery, D. Lee \& O. Oztekin (2008) How do large banking organizations manage their capital ratios? Journal of Finance Services Research 34, 123-149.

A. N. Berger, R. J. Herring \& G. P. Szegö (1995) The role of capital in financial institutions. Journal of Banking and Financial 19, 393-430.

F. Black \& M. Scholes (1973) The pricing of options and corporate liabilities, The Journal of Political Economy 81, 637-654.

P. Borochin \& J. Yang (2014) Options, risks, and the value of financial flexibility: Implications for financing constraints, Working Paper.

E. Brewer, G. G. Kaufman \& L. D. Wall (2008) Bank capital ratios across countries: Why do they vary? Journal of Finance Services Research 34, 177-201.

M. Brunnermeier, A. Crockett, C. A. E. Goodhart, A. Persaud \& H. S. Shin (2008) The Fundamental Principles of Financial Regulation, Geneva Reports on the World Economy, 11, 1,108 .

C. W. Calomiris (2012) Getting the right mix of capital and cash requirements in prudential bank regulation, Journal of Applied Corporate Finance 24, 33-41.

C. W. Calomiris, F. Heider \& M. Hoerova (2015) A theory of bank liquidity requirements, Columbia Business School Research Paper, 14-39.

L. Chernykh \& R. A. Cole (2014) How should we measure bank capital adequacy? A (simple) proposal, Working Paper.

M. M. Cornett, J. McNutt, P. E. Strahan \& H. Tehranian (2011) Liquidity risk management and credit supply in the financial crisis, Journal of Financial Economics 101, 297-312.

D. W. Diamond \& R. G. Rajan (2000) A theory of bank capital, Journal of Finance 55, 2431-2465.

D. W. Diamond \& R. G. Rajan (2001) Banks and liquidity, The American Economic Review 91, 422-425.

M. J. Flannery (1994) Debt maturity and the deadweight cost of leverage optimally financing banking firms, American Economic Review 84, 320-331.

M. Flannery \& S. Nikolova (2004) Market discipline of US financial firms: Recent evidence and research issues, In Market Discipline Across Countries and Industries (C. Borio. W. Hunter, G. Haufman \& K. Tsatsaronis, eds.), pp. 87-100. Cambridge: MIT Press.

R. Gropp (2004). Bank market discipline and indicatoris of banking system risk: The european evidence, In Market Discipline Across Countries and Industries (C. Borio. W. Hunter. G. Kaufman \& K. Tsatsaronis, eds.), pp. 101-117. Cambridge: MIT Press.

V. Ivashina \& D. Scharfstein (2010) Bank lending during the financial crisis of 2008, Journal of Financial Economics 97, 319-338.

S. C. Myers \& R. G. Rajan (1998) The paradox of liquidity, Quarterly Journal of Economics 113, 733-771.

S. Mortal \& N. Reisel (2013) Capital allocation by public and private firms, Journal of Financial and Quantitative Analysis 48, 77-103. 
E. Ofek, M. Richardson \& R. Whitelaw (2004) Limited arbitrage and short sales restrictions: Evidence from the options markets, Journal of Financial Economics 74, 305-342.

M. A. Petersen (2009) Estimating standard errors in finance panel data sets comparing approaches, Review of Financial Studies 22, 435-480.

A. D. Roy (1952) Safety first and the holding of assets, Econometrica 20, 431-449.

J. A. C. Santos (2001) Bank capital regulation in contemporary banking theory: A review of the literature, Financial Markets. Institutions $\mathcal{E}$ Instruments 10, 41-84.

A. V. Thakor (2014) Bank capital and financial stability: An economic tradeoff or a faustian bargain? Annual Review of Financial Economics 6, 185-223. 